\title{
Crop modelling: towards locally relevant and climate-informed adaptation
}

\author{
Louise Beveridge $^{1,2}$ (D) $\cdot$ Stephen Whitfield $^{1} \cdot$ \\ Andy Challinor ${ }^{2}$
}

Received: 21 December 2016 / Accepted: 16 February 2018 /Published online: 4 March 2018

(C) The Author(s) 2018. This article is an open access publication

\begin{abstract}
A gap between the potential and practical realisation of adaptation exists: adaptation strategies need to be both climate-informed and locally relevant to be viable. Place-based approaches study local and contemporary dynamics of the agricultural system, whereas climate impact modelling simulates climate-crop interactions across temporal and spatial scales. Cropclimate modelling and place-based research on adaptation were strategically reviewed and analysed to identify areas of commonality, differences, and potential learning opportunities to enhance the relevance of both disciplines through interdisciplinary approaches. Cropmodelling studies have projected a $7-15 \%$ mean yield change with adaptation compared to a non-adaptation baseline (Nature Climate Change 4:1-5, 2014). Of the 17 types of adaptation strategy identified in this study as place-based adaptations occurring within Central America, only five were represented in crop-climate modelling literature, and these were as follows: fertiliser, irrigation, change in planting date, change in cultivar and area cultivated. The breath and agency of real-life adaptation compared to its representation in modelling studies is a source of error in climate impact simulations. Conversely, adaptation research that omits assessment of future climate variability and impact does not enable to provide sustainable adaptation strategies to local communities so risk maladaptation. Integrated and participatory methods can identify and reduce these sources of uncertainty, for example, stakeholder's engagement can identify locally relevant adaptation pathways. We propose a research agenda that uses methodological approaches from both the modelling and place-based approaches to work towards climate-informed locally relevant adaptation.
\end{abstract}

Electronic supplementary material The online version of this article (https://doi.org/10.1007/s10584-018$2160-z)$ contains supplementary material, which is available to authorized users.

Louise Beveridge

eelb@1eeds.ac.uk

1 Sustainability Research Institute, School of Earth and Environment, University of Leeds, Leeds, UK

2 Institute for Climate and Atmospheric Science, School of Earth and Environment, University of Leeds, Leeds, UK 


\section{Introduction}

Effective adaptation of agricultural systems to climate change requires cross-scale and crossdisciplinary understanding. In order for agricultural technologies or livelihood changes to be accepted and maintained, they should be appropriate to local socio-cultural and agroecological conditions. In order to be resilient to future climates, agricultural and rural development must be informed and designed around an understanding of longer term climatic change, which often requires wider scale, longer term and proactive planning. Thus, adaptation strategies need to be climate-informed and locally relevant. Major complexities exist in both the study of agricultural livelihoods and the study of future climate change and its potential impact. Each research community has a unique set of challenges, assumptions and an associated epistemology. These differences are potential barriers to cross-disciplinary research and knowledge exchange, so it is important to ask where are the shared goals and commonalities that can be exploited to further the field of adaptation science.

There is a recognised need to develop an adaptation science that is not limited by discipline (Klein et al. 2014; Smit and Wandel 2006; Bhaskar et al. 2010) and is able to produce 'salient, credible and legitimate' knowledge that is relevant and responsive to the multiple temporal and spatial scales and the social, economic, political and environmental processes of agricultural systems (Keating and McCown 2001; Patt and Gwata 2002; Meinke et al. 2009). This is evident for example in the Future Earth strategic research agenda (Future Earth 2014), and in a growing variety of 'climate service' initiatives that seek to combine knowledge and disciplinary insights in contributing towards climate-informed locally relevant adaptation planning (WMO 2014). However, there are many barriers and challenges associated with crossdisciplinary research across individual, community and institutional levels (National Academy of Sciences 2005; Naess 2013; Shaman et al. 2013). For example, the socioeconomic complexities of agricultural and non-agricultural pathways of decision-making and change can be difficult to represent within the limitations of physical simulation models. At the same time, the complexity of the physical science that underpins modelling approaches can be difficult to communicate to those without specific technical expertise (Whitfield 2013). These challenges can be compounded by the epistemological and cultural differences between physical science disciplines and the societal research and action.

In this paper, we specifically focus on the challenge of integrating place-based and cropclimate modelling research. Place-based research focuses on the local and contemporary dynamics of the agricultural system and in doing so can represent local and experiential knowledge. Complimentarily, climate-crop modelling has the capacity to project scenarios of future climatic variability and extend understandings of farming systems across spatial and temporal scales. For modellers, the process of working with stakeholders and place-based researchers can enable to identify a set of wider contributing factors that engage with and affect agricultural livelihood decisions and food security, such as food storage capacity, political security, policy incentives, capital, cultural identity, access to inputs and markets and sustainability goals. This breadth of system boundary and system thinking makes apparent the challenge of a robust predictive tool for the assessment of future food security (Whitfield et al. 2015a, b).

Through a systematic literature review, we identify the contribution that these distinct communities make to agricultural adaptation research. Through this analysis, we identify key areas where the two communities can learn from and inform each other, focussing on practical objectives for better integration of research, such as, how can crop models simulate 
more realistic adaptation? We first identify the epistemologies of adaptation research (Section 2.1), before going on to describe the two main approaches that we identify (Section 2.2, modelling; and Section 2.3, place-based). Using the methods outlined in Section 3, we then employ this typology to analyse adaptation research in Central America and to identify the commonalities and differences between the two fields (Sections 4 and 5). The paper concludes with a suggested research agenda for tackling some of these asymmetries and building an interdisciplinary evidence base to inform agricultural climate change adaptation (Sections 5 and 6).

\section{Background}

\subsection{Epistemologies}

"To understand the world it has seemed necessary to analyse it by breaking it into many pieces. But to act in the world, to try to address the issues for which highly specialized knowledge was presumably sought, we need somehow to reassemble all the pieces". Easton et al. 1991—“Divided Knowledge: Across Disciplines, Across Cultures"

As academic disciplines have evolved, they have inevitably developed their own theoretical bases, norms of investigation and accepted epistemologies. The characteristic positivism of the physical sciences underpins the systematic hypothesis testing and controlled experimentation that have become synonymous with these disciplines. This contrasts markedly with a constructivist epistemology that suggests that our knowledge of the world is not objective but subject to human constructs, which has become the basis of branches of sociological study and participatory forms of knowledge co-production (Berger and Luckmann 1966; Giddens 1976). Fundamental differences in philosophies of knowledge are manifest in diverse disciplinary cultures, approaches, methods and languages (Biglan 1973).

Developments in general systems theory (Von Bertalanffy 1968) are associated with attempts to reintegrate or work across disciplines as a means to understanding the complexities of the real world. It has broad applications in farming systems (Collinson 2000; Darnhofer et al. 2012), socio-ecological systems (Folke 2006; Young et al. 2006; Lambin and Meyfroidt 2010) and climate systems (Franzke et al. 2015). Real-world systems are inextricably physical, natural, social, economic, cultural and political in nature, resulting in system behaviours that individual disciplines lack the tools to understand and predict. The physical processes of climatic change, for example, are not independent of the underlying social, economic, political causes of anthropogenic emissions, which are themselves not independent of the agricultural and land management choices or market properties that shape vulnerabilities to different climate regimes. One of the important contributions of general systems research has been recognition of valuing local and contextual knowledge. Farming systems research, in particular, has been synonymous with innovations in participation and the 'farmer first' movement in research in developing country contexts (Chambers 1990; Scoones et al. 2009). Tools of participatory rural appraisal and participatory crop breeding engage stakeholders within the research process, recognise the relevance and value of local knowledge and thus have sought to make it central to intervention planning within farming systems. But the integration of these place-based knowledge with those of physical and modelling science has continued to 
represent a challenge which is arguably an epistemological one (a challenge of different understandings of knowledge) as much as it is a methodological and practical one.

\subsection{Modelling approaches}

The modelling community that is addressing agricultural adaptation generally subscribes to topdown approaches described in Intergovernmental Panel on Climate Change (IPCC) Assessments (Mimura et al. 2014), as depicted in Fig. 1a, using simulations to project a future impact as a starting point. The term 'Crop modelling' refers here to studies that use process-based crop models to simulate the impact of weather, climate and management decisions on yield. Crop-climate modelling is further distinct in its use of general circulation models (GCMs) with crop models to project the impact of future climate change scenarios on yield or production. This approach has been applied from field to global scales (e.g. Jones et al. 2003; Challinor et al. 2004, 2014). Research to date has highlighted where significant changes in productivity are expected in response to climate change across the world, as well as modelling changes in crop suitability (Lane and Jarvis 2007; Rosenzweig et al. 2014; Rippke et al. 2016). Vermeulen et al. (2013) illustrate how crop-climate modelling and analyses can pre-emptively inform the magnitude of adaptation required across a range of time scales. Process-based crop models have also been applied to direct future research and crop breeding (Heslot et al. 2014; Falloon et al. 2015; Challinor et al. 2016). The benefits of different adaptation strategies have often been compared by their relative impact on yield (e.g. Meza et al. 2008; Lobell et al. 2008; Challinor et al. 2009).

Challenges facing crop modellers attempting to inform adaptation are detailed in Challinor et al. (2018), to summarise: there is currently a limited model representation of the true dynamic adaptive management used by farmers (Quinn et al. 2011); there is an inherent difficulty in the attribution of a yield change to an adaptation compared to a non-adapted control (Lobell 2014); and there is the responsibility for research to contribute to knowledge and address societal challenges (Lubchenco 1998). The agricultural model intercomparison project (AgMIP) has explicitly recognised the need

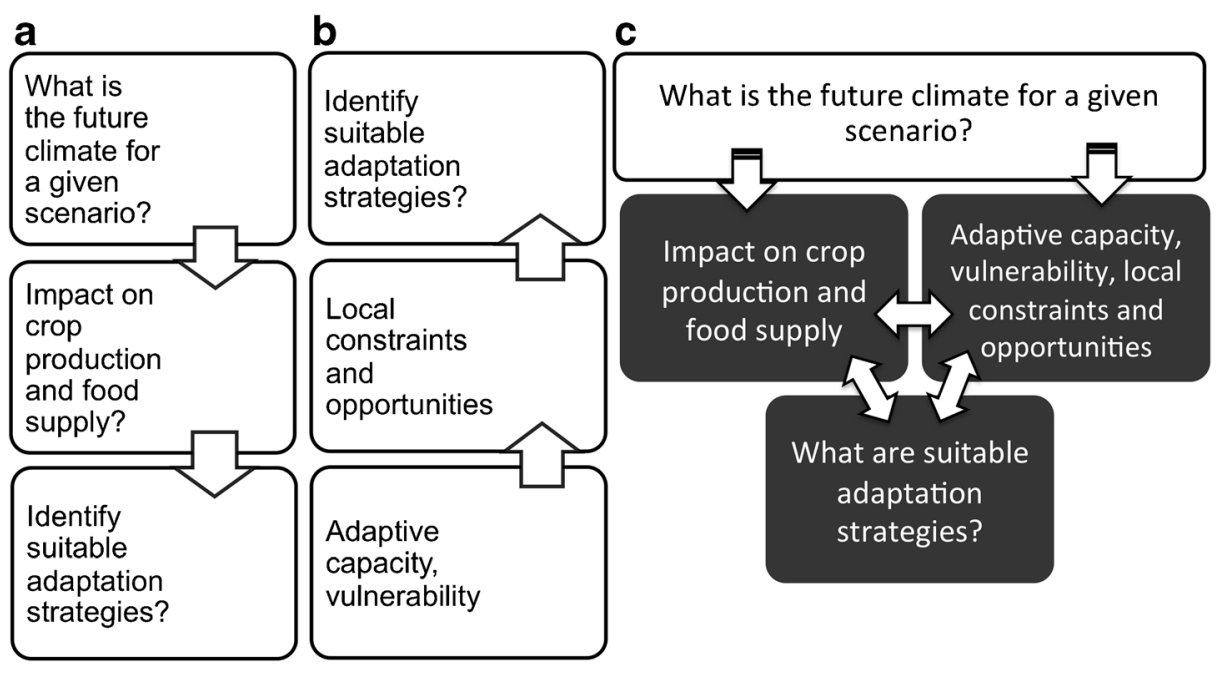

Fig. 1 Diagram of workflow typically used in top-down (a) and bottom-up (b) approaches to studying adaptation, developed from IPCC SREX Report (IPCC 2012) and Mimura et al. (2014), and a proposed iterative and interdisciplinary workflow (c) 
for modelling communities to engage with stakeholders throughout the modelling process (Rosenzweig et al. 2015). However, the black-box nature of process-based crop models can be a barrier to their use in adaptation research as processes of parameterisation, bias correction, model stacking, and ensembles can propagate uncertainty, such that setting up of simulations and interpretation of output to determine risk requires a high degree of skill- and discipline-specific knowledge (Whitfield 2013).

\subsection{Place-based approaches}

"Place-based" is a term used here to describe methodological approaches that encounter context specific knowledge, as in place-based modelling for natural-disaster response, place-based policy and place-based teaching in education (Cutter et al. 2008; Barca et al. 2012). In the context of this research, we use the term place-based to refer to approaches that use context-specific or site-specific information and knowledge to inform adaptation research, akin to the term bottom-up in IPCC literature (Mimura et al. 2014), as depicted in Fig. 1b. Such approaches frame adaptation within a local context, considering factors that are specific to the geographical boundary in which the study occurs, for example livelihoods, culture, agro-ecology and constraints and opportunities experienced by stakeholders (e.g. Smit and Piliosova 2003; Claessens et al. 2012; Mimura et al. 2014). Placebased approaches may represent the influence of social structures, such as external actors, power and governance on the adaptation process (e.g. Arora 2012). Multiple framings and theoretical approaches can be encompassed within place-based research by this definition, including the application of adaptive capacity and vulnerability assessments (Olsson et al. 2014), studies of historical adaptation (Campos et al. 2013) and studies of agricultural decision-making and risk (Orlove et al. 2010).

The term "local knowledge" is used here to describe the knowledge held by a given society in a specific location. It is used to represent multiple sources of knowledge such as local ecological knowledge, indigenous knowledge or scientific knowledge, with recognition that these sources are not always distinct (Agrawal 1995). From an underlying constructivist epistemology, the drawing on and integration of local knowledge, as a way of interpreting context-specific realities, is a common trait of place-based research (Dessai et al. 2004). The World Bank handbook 'Participatory scenario development approaches for identifying propoor adaptation options' (The World Bank 2010) serves as an example of an applied methodology that engages stakeholder to inform adaptation decisions.

A limitation of place-based adaptation research is the capacity to work across scale: generalising results outside of the study group, study area and across timescales. The dynamic process of adaptive agricultural decision-making is an outcome of experience, histories (Dixon et al. 2014) and future perceived risk. In-depth but timeframe-specific studies therefore lack the temporal scale needed to understand cycles of adaptation, which can often be generational (Feola et al. 2015). An understanding of how risks may be reinforced or dampened by future climate change is also missing from place-based adaptation research that does not engage with climate and impact knowledge.

\section{Methods}

A meta-analysis of simulations of climate change impact on yield (with and without adaptation) was used to evaluate crop impact modelling literature. A database of over 1700 
simulations, from 91 studies, as described in Challinor et al. (2014) and IPCC (2014) was used as an initial source of studies. Known relevant studies published since 2014 were added. Placebased literature on adaptation was evaluated through a separate strategic literature review of adaptation research that focussed within the case study region of Central America. A full description of the criteria for inclusion, and information recorded from included studies, is detailed in Table 1 of Supplementary Material.

\section{Results}

\subsection{Adaptation strategies}

The findings of the review indicate the limited proportion of on-farm strategies that climatecrop impact models currently represent in their application to the study of adaptation. Of the two different approaches, the range and focus of adaptations assessed in crop-modelling literature are only a sub-section of the range represented in place-based studies; fertiliser, irrigation change in cultivar, change in planting date and change in area cultivated were represented in modelling studies. These and 12 others were represented in place-based studies in Central America with a greater range of adaptation types (Fig. 2 and Table 2 of Supplementary Material).

\subsection{Assessing adaptation outcomes in a place-based context}

Out of the nine fully reviewed place-based studies, six reported practices for agricultural adaptation without attributing a change in production to the specific adaptation. Rather, qualitative evidence for the benefit of a practice was the cumulative result of questionnaires and focus groups with farmers based on their own perceived experiences of climate impacts on their crops, livelihoods and adaptation (Campos et al. 2013; Baca et al. 2014; Bacon et al. 2014; Eakin et al. 2014; Milan and Ruano 2014; Rahn et al. 2014). Porch et al. (2007) did calculate changes in production to assess the relative effect of climate variability as a driver of migration. They use their analysis to stress that vulnerability will be exacerbated by climate change, but without use of future climate scenarios or projections. Only four studies used climate projections to construct a quantitative scenario of future climate impact as a baseline for adaptation: Baca et al. (2014) and Rahn et al. (2014) both used downscaled GCM projections from SRES A2a, to drive a climate suitability model (MAXENT) to produce an indicator of exposure to climate change. This indicator of climate change exposure was then used as a point of discussion with stakeholders with the aim to identify locally relevant adaptation strategies based on this information. Ruane et al. (2013) and Schmidt et al. (2012) used future projections to drive process-based crop models; DSSAT, Ecocrop and CERES-Maize models were utilised to give a quantitative projection of future yield change. Ruane et al. (2013) illustrates the importance of household variables as input parameters to improve impact projections for yield on a regional scale. The study by Schmidt et al. (2012) uses crop impact models with climate projections (for maize-bean systems) and household information to calculate a household-specific indicator of exposure to climate change and adaptive capacity. This has enabled them to produce information that is informed by largescale modelled future climate scenarios (A2, business as usual) with quantified uncertainty (generated by use of GCM ensembles, input in to DSSAT), but that is also locally relevant to 


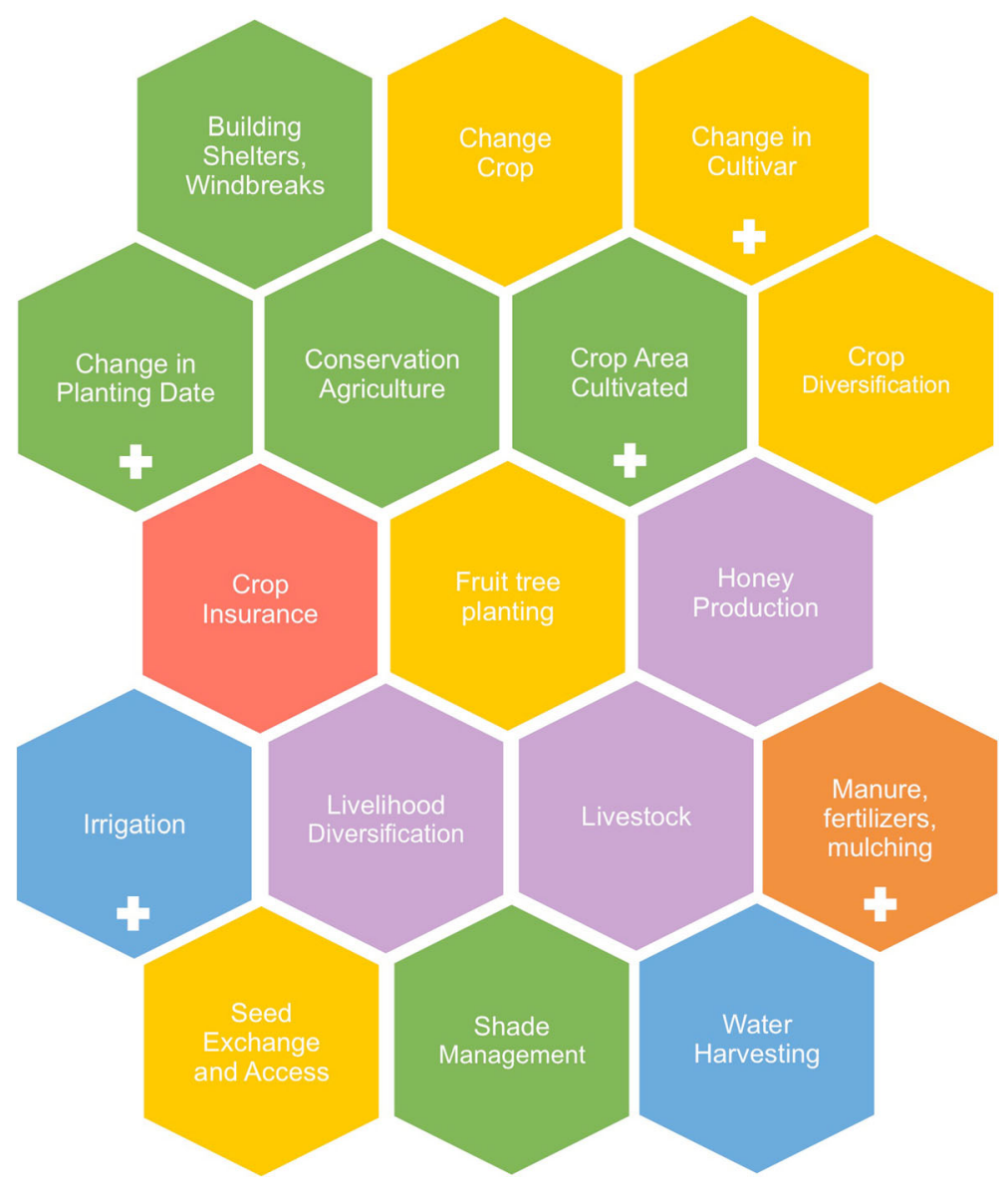

Fig. 2 Adaptation strategies represented in place-based literature, with a cross to denote those also represented in crop-modelling literature. Types of adaptation include change to inputs (orange), water management (blue), crop management (green), crop type (yellow), crop insurance (red) or livelihood (purple)

the specific area using local case studies. Studies by Baca et al. (2014) and Rahn et al. (2014) and Ruane et al. (2013) all discussed adaptation options post-impact assessment; there were no examples of studies that used an iterative process between researchers (impacts modeller, social scientist) and farmers to model the impact of local relevant adaptation strategies on households.

\section{Discussion}

Arnell's (2010) review of adaptation studies illustrated a gap between the potential and practical realisation of adaptation reported in literature. He suggests that local context might be a factor missing from existing adaptation studies that has the potential to bridge this observed gap. Our study has used a strategic review to assess whether place-based research that typically engages with local knowledge and local conditionality is being integrated with 
conventional physical modelling approaches to studying adaptation. In doing so, we identified explicitly the differences in approach, scope and aims of the two communities.

One of the key differences between approaches used by the modelling and place-based communities is the breadth of the systems studied (the system boundary, in modelling parlance). The crop-modelling studies reviewed simulated the crop, the climate, soil and sometimes to a limited extent, management practices. Their scale was field, regional or global, and they tended to focus on the accuracy and precision of yield prediction, uncertainty in future climate change and mitigation potential. Staple crops, namely wheat, rice or maize, were the represented crops in the majority of studies. The objective of adaptation was framed in model studies as to maintain or optimise yield under future climate conditions. The aim of crop-climate modelling studies was rarely to inform farm-level adaptation decisions, which may in part explain the limited capacity of crop-climate models to represent the range of adaptation occurring at that scale. However, these results suggest that given the flexibility and range of adaptation used by farmers, the comparatively limited range used in crop climate modelling may systematically bias projections of climate impact at regional to global scales if the error introduced at a plot scale is propagated through the up-scaling process (Hansen and Jones 2000). The regional scale of the place-based literature review (Central America) means that while identifying key limitations in modelling approaches, this study will only have highlighted a portion of the plethora of adaptation strategies used globally. Although cropmodelling effort to date has focussed on improving simulations of these five adaptation strategies, there is potentially greater understanding to be generated by starting to address the breadth of adaptation used in real-life farm management.

In comparison, place-based studies tended to have a broader scope, in systems terms, than modelling studies. The researchers or participants often defined the scope during the process of discussing and identifying relevant adaptations. This area of literature included a much wider range of adaptations, including crop insurance an economic adaptation, and more transformational type changes, such as diversification of livelihoods to change crops, introduce livestock or supplement income with off-farm sources. Other crop management-based adaptations included planting an over-story (agro-forestry), fruit tree planting (as individual crop or agro-forestry system), intercropping, windbreaks, reduced tillage (conservation agriculture) and crop-residue, manure or mulch (conservation agriculture), all of which affect production through interactions with soil-nutrient balance, soil-water balance, soil-water structure or wind, pest and disease damage. Finally, direct water management was another type of adaptation that aimed to reduce the impact of water stress on production by stabilising water access through water harvesting or changes in irrigation. The potential impact of an adaptation was more often informed by qualitative information, rather than discreetly calculated as a yield change. Adaptation recommendations made were therefore the most relevant at a local scale and at the time of the study. Regarding the use of climate information, Ruane et al. (2013) provide an example of how a place-based study can incorporate GCMs to make risk-based projections of possible future climates to inform adaptation decisions. However, we found that in some other studies, the magnitude or nature of future climate change was discussed only as a justification, rather than given as a calculated risk based on current climate science. The focus of place-based studies was often the household or community, a measure of production, income, wellbeing, climate exposure or resilience. This reflects the broader set of objectives and drivers of household scale adaptation, which although are often related to agricultural production and food security are not centrally framed around maintaining maximum yield. 
Given the corresponding strengths and limitations of each approach discussed so far, summarised in Table 1, an obvious potential development for adaptation research is to integrate the capacities of each approach to enable local knowledge and context to inform modelling research approaches and vice versa. A mechanism for doing this is by integrating the previously identified top-down and bottom-up approaches from Fig. 1a, b, into the process represented in Fig. 1c. In this new framework, place-based and crop-climate modelling methodologies are both equally viable starting points to identify relevant adaptation strategies. Through a clockwise or counter-clockwise workflow, the local viability and impact of a strategy, given a future climate scenario, can then be assessed in iterative cycles in a participatory way. It is in this iterative link between disciplines where asymmetries may become most apparent as a barrier to progress, especially with respect to the differences in scale of systems being studied and data availability. But equally, this suggests it is the interface where productive steps forward in understanding and integration can be made. The following section sign-posts four pathways to enable better knowledge and information exchange between communities to work towards this iterative adaptation research process, and these are as follows: (i) descriptions of practices, (ii) developing adaptation within crop-climate modelling, (iii) modelling with stakeholder engagement and (iv) understanding the objectives of adaptation.

\subsection{Descriptions of practices}

A shared understanding and definition of an adaptation strategy is a pre-requisite of knowledge and information transfer between communities. In some cases, general terms and titles are used in place-based literature, such as conservation agriculture or agro-forestry. While these terms have general agreed definitions within social literature, they are open to interpretation (to enable locally appropriate adaptation). This makes forming an evidence base, datasets and model parameterisation from which to assess their potential impact across temporal or spatial scales difficult. Explicit descriptions of an adaptation, where discussed, would aid translation between place-based and modelling research. For example, Rahn et al. (2014) describe their use of the term 'soil conservation' was specifically in reference to planting within contour lines and using organic fertiliser and pesticide inputs. This could be more easily translated into a model impact assessment through adjusting soil-water retention, pest-and-disease or nutrition

Table 1 A summary of the strengths $(+)$ or limited capacity $(-)$ of crop-climate modelling and place-based approaches to studying adaptation

\begin{tabular}{lc}
\hline Crop-climate modelling & Place-based \\
\hline + Calculating risk and uncertainty of climate impacts & $\begin{array}{c}\text { + Identifying local constraints and opportunities for } \\
\text { adaptation } \\
\text { + Integrating local values and knowledges }\end{array}$ \\
$\begin{array}{l}\text { Quantifying the impact of an adaptation on yield } \\
\text { or production }\end{array}$ & + Representing the multiple aspects of food security \\
+ Representing a range of possible future outcome & and trade-offs between them \\
through socio-economic scenarios & + Assessing the equability of an impact within \\
+ Providing food availability trends for & communities and identifying vulnerable groups \\
regional-global scales & + Engaging with stakeholders \\
+ Spatial and temporal scaling & - Assessing the impact of adaptation under future \\
- Representing the breadth and agency of farm scale & climate variability \\
adaptation decisions & - Scaling up from local \\
\hline Identifying and addressing locally critical factors & .
\end{tabular}


stress parameters, depending on the level of process detailed in the crop model, and where suitable data exists. Other reviewed studies used the same term 'soil conservation' more ambiguously, without a description of which specific practices were being referred to, which removes the possibility of assessing the potential benefits of the adaptation under future climate projections.

\subsection{Developing adaptation within crop-climate modelling}

A logical step forward for the crop-modelling community is the improvement of adaptation within modelling studies (Challinor et al. 2018). We further highlight the need to include new types of adaptation into the scope of modelling studies, as well as the existing focus on improving simulation of the five identified strategies. We have illustrated how strategically reviewing local place-based literature can identify the most relevant adaptations (geographical, culturally or socio-economically) to consider. Engagement of stakeholders such as farmers and agronomists using place-based methods is an alternative methodological approach to refine almost infinite combinations of potential adaptation strategies into manageable scenarios that are relevant to the study area and scale. Simulating complex, and locally parameterised, land management, such as conservation agriculture or crop-livestock interactions (particularly so that temporal change in these systems might be analysed) represents an area for potential development. Windbreak impacts, for example, might be integrated into crop models through a modification of evapotranspiration values. Where an identified adaptation cannot be integrated into crop-climate modelling effort directly, e.g. a livelihood shift away from agriculture, this process still enables a researcher to highlight an assumption of the study. Sensitivity analysis of the impact of local and relevant adaptations (e.g. to evaluate long-term requirements for water harvesting to address crop water deficits) on production may be a good starting point for the crop-climate modelling community to gain perspective on the magnitude of change associated with more realistic adaptation. Crop models developed for small-scale farm decision support have already developed parameter sets for some of these more refined management-based processes such as tillage, mulching or intercropping, and their impact on soil-water processes and production (Jones et al. 2017). The main factor stopping these processes of management and adaptation from being scaled up with crop climate modelling studies is the perceived lack of, or lack of access to, data on management strategies at relevant scales for climate impact studies (Rivington and Koo 2010), which further supports the need for detailed descriptions of practices to enable systematic collection of management and adaptation data.

\subsection{Modelling with stakeholder engagement}

As well as being predictive, modelling approaches can be utilised as a tool to build a shared understanding of a concept, and for knowledge exchange as acquired though the process of model building and assessment. In this way, participatory modelling can be used to aid communication and integrate stakeholder and scientists held knowledge (Jakku and Thorburn 2010). This type of participatory approach has also been shown to increase the uptake and use of resulting climate information, due to the trust gained through the interaction between stakeholder and researcher (Ziervogel and Opere 2010). Thus, to develop place-based adaptation strategies that are informed by climate projections and impact models requires communicable and transparent modelling efforts (Whitfield 2014). This may contradict a 
current trajectory of crop-climate modelling research towards investment in ever-greater model complexity and increasing computer power (Whitfield 2013).

\subsection{Understanding the objectives of adaptation}

Modelling approaches commonly represent management with either no adaptation or optimised decision-making (adaptation for optimal yield) (Easterling et al. 2003). However, place-based research has provided evidence that challenges the appropriateness of this binary view, where specific management strategies are being favoured due to drivers other than yield optimisation. For example, in rural developing conditions, strategies such as keeping fruit trees and crop diversification contribute significantly to maintaining household nutrition, sometimes at a cost to optimising yield or income (Fanzo et al. 2013; Pellegrini and Tasciotti 2014). Similarly, agro-forestry can contribute to both food and sustainability goals through simultaneous production and carbon sequestration. Household agricultural decisions are also often made to reduce or spread risk rather than optimise production, especially in food insecure households where income diversification is common (Dercon and Krishnan 1996). Risk is increased in low-income agricultural households when strategies such as borrowing money, or selling assets and livestock, are used to generate the income needed to purchase inputs seasonally, which results in a debt or loss of capital that is expected to be repaid on harvest. But other adaptation strategies such as buying crop insurance, participating in payment for work programs or sourcing off-farm income can enable farmers to innovate taking a bigger risk, for example, trying a new variety, investment in cash crops or implementing a new soil management practice (Eakin 2005). These contextual objectives of agricultural change and decision-making are overlooked by traditional yield-centric modelling approaches, but could start to be addressed though an iterative research cycle with input from stakeholders (Fig. 1c). If crop-climate modelling studies are able assess and communicate the risks associated with different adaptation strategies in a local context but across future projections, the chance of unexpected negative outcomes from adaptive intervention can be reduced (Whitfield et al. 2015a, b).

\section{Conclusions}

The challenge of producing locally relevant and climate-informed adaptation strategies for agriculture is complex. Adaptive decisions transcend spatial and temporal scales and interact with social, economic and environmental systems. Cross-disciplinary approaches can build our capacity to identify and understand critical factors that drive and limit agricultural adaptation at the local scale. They can also be used to assess the potential impact of an identified adaptive strategy across spatial and temporal scales, including under future climate change scenarios, which is of particular relevance to policy decisions. There are practical steps needed for successful iterative working between crop-climate modelling and place-based communities. Crop-climate modelling research needs to better address adaptation in climate change studies. A meta-analysis of modelling studies projected a 7-15\% mean yield change with adaptation compared to a non-adaptation baseline (Challinor et al. 2014). These studies collectively represent adaptation through five strategies (irrigation, planting date, cultivar, fertilisation, planted area); however, this approach does not represent the diversity and breadth of adaptation strategies used by farmers. To better represent adaptation, crop-climate modelling 
approaches may need a paradigm expansion to be implemented within more system and placebased approaches that can represent local context, knowledge and aspects of food security other than availability (e.g. nutrition, access, utilisation and stability). A collective action towards building consistent and accessible datasets on management and adaptation is also a pre-requisite to incorporating more adaptation processes into crop-climate modelling studies. Building trust between researcher and stakeholder will be essential for successful iterative research and assessment of locally relevant adaptation. Participatory and iterative modelling, as commonly used in place-based approaches, is a potential tool to do this, by aiding communication, developing a shared understanding and set of definitions between researchers from different backgrounds and stakeholders and improving impact and uptake of adaptation science.

Funding information This research was funded by the Natural Environment Research Council, with support from Bioversity of CGIAR.

Open Access This article is distributed under the terms of the Creative Commons Attribution 4.0 International License (http://creativecommons.org/licenses/by/4.0/), which permits unrestricted use, distribution, and reproduction in any medium, provided you give appropriate credit to the original author(s) and the source, provide a link to the Creative Commons license, and indicate if changes were made.

\section{References}

Agrawal A (1995) Dismantling the divide between indigenous and scientific knowledge [online]. Dev Chang 26(3):413-439

Arnell NW (2010) Adapting to climate change: an evolving research programme. Clim Chang 100(1):107-111

Arora S (2012) Farmers' participation in knowledge circulation and the promotion of Agroecological methods in South India [online]. J Sustain Agric 36:207-235

Baca M, Laderach P, Haggar J, Schroth G, Ovalle O (2014) An integrated framework for assessing vulnerability to climate change and developing adaptation strategies for coffee growing families in mesoamerica. PLoS One 9(2):e88463

Bacon CM, Sundstrom WA, Flores Gómez ME, Ernesto Méndez V, Santos R, Goldoftas B, Dougherty I (2014) Explaining the 'hungry farmer paradox': smallholders and fair trade cooperatives navigate seasonality and change in Nicaragua's corn and coffee markets. Glob Environ Chang 25(1):133-149

Barca F, Mccann P, Rodríguez-Pose A (2012) The case for regional development intervention: place-based versus place-neutral approaches. J Reg Sci 52(1):134-152

Berger P, Luckmann T (1966) The social construction of reality: a treatise in the sociology of knowledge. Anchor Books, London

Bhaskar R, Frank C, Hoyer KG, Naess P, Parker J (2010) Interdisciplinarity and climate change: transforming knowledge and practice for our global futures. Ontological Explorations. Routledge, New York, p 1-26

Biglan A (1973) The characteristics of subject matter in different academic areas. J Appl Psychol 57(3):195

Campos M, Herrador D, Manuel C, McCall M (2013) Adaptation strategies to climate change in two rural communities in Mexico and El Salvador. Boletín De La Asociación De Geógrafos Españoles 61:433-436

Challinor AJ, Wheeler TR, Craufurd PQ, Slingo JM, Grimes DIF (2004) Design and optimisation of a large-area process-based model for annual crops. Agric For Meteorol 124:99-120

Challinor A, Wheeler T, Hemming D, Upadhyaya H (2009) Ensemble yield simulations: crop and climate uncertainties, sensitivity to temperature and genotypic adaptation to climate change [online]. Clim Res 38 : 117-127 Accessed 6 Aug 2015

Challinor AJ, Watson J, Lobell DB, Howden SM, Smith DR, Chhetri N (2014) A meta-analysis of crop yield under climate change and adaptation. Nat Clim Chang 4:1-5

Challinor AJ, Koehler AK, Ramirez-Villegas J, Whitfield S, Das B (2016) Current warming will reduce yields unless maize breeding and seed systems adapt immediately. Nat Clim Chang 6(10):954

Challinor A, Mueller C, Asseng S, Deva C, Nicklin KJ, Wallach D, Vanuytrecht E, Whitfield S, Ramirez-Villegas J, Koehler A-K (2018) Improving the use of crop models for risk assessment and climate change adaptation. Agric Syst 159:296-306 
Chambers RG (1990) Farmer-first: a practical paradigm for the third agriculture. In: Altieri MA, Hecht SB (eds) Agroecology and small farm development. CRC Press, USA, p 237-244

Claessens L, Antle JM, Stoorvogel JJ, Valdivia RO, Thornton PK, Herrero M (2012) A method for evaluating climate change adaptation strategies for small-scale farmers using survey, experimental and modeled data [online]. Agric Syst 111:85-95

Collinson MP (2000) A history of farming systems research. CABI, Wallingford

Cutter SL, Barnes L, Berry M, Burton C, Evans E, Tate E, Webb J (2008) A place-based model for understanding community resilience to natural disasters. Glob Environ Chang 18(4):598-606

Darnhofer I, Gibbon D, Dedieu B (2012) Farming systems research: an approach to inquiry. In: Farming systems research into the 21st century: the new dynamic. Springer, Dordrecht. pp 3-31

Dercon S, Krishnan P (1996) Income portfolios in rural Ethiopia and Tanzania: choices and constraints. J Dev Stud 32(6):850-875

Dessai S, Adger WN, Hulme M, Turnpenny J, Köhler J, Warren R (2004) Defining and experiencing dangerous climate change. Clim Chang 64(1):11-25

Dixon J, Stringer L, Challinor A (2014) Farming system evolution and adaptive capacity: insights for adaptation support [online]. Resources 3(1):182-214

Eakin H (2005) Institutional change, climate risk, and rural vulnerability: cases from Central Mexico. World Dev 33(11):1923-1938

Eakin H, Tucker CM, Castellanos E, Diaz-Porras R, Barrera JF, Morales H (2014) Adaptation in a multi-stressor environment: perceptions and responses to climatic and economic risks by coffee growers in Mesoamerica. Environ Dev Sustain 16(1):123-139

Easterling WE, Chhetri N, Niu X (2003) Improving the realism of modeling agronomic adaptation to climate change: simulating technological substitution. Clim Chang 60(1-2):149-173

Easton D, Schelling CS, Arts, A.A. of \& Sciences (1991) Divided knowledge: across disciplines, across cultures. JSTOR, Newbury Park

Falloon P, Bebber D, Bryant J, Bushell M, Challinor AJ, Dessai S, Gurr S, Koehler A (2015) Using climate information to support crop breeding decisions and adaptation in agriculture. World Agric 1(5):25-42

Fanzo J, Hunter D, Borelli T, Mattei F (eds) (2013) Diversifying foods and diet: using agricultural biodiversity to improve nutrition and health. Issues in Agricultural Biodiversity, London

Feola G, Lerner AM, Jain M, Montefrio MJF, Nicholas KA (2015) Researching farmer behaviour in climate change adaptation and sustainable agriculture: lessons learned from five case studies. J Rural Stud 39:74-84

Folke C (2006) Resilience: the emergence of a perspective for social-ecological systems analyses. Glob Environ Chang 16(3):253-267

Franzke CL, O'Kane TJ, Berner J, Williams PD, Lucarini V (2015) Stochastic climate theory and modeling. Wiley Interdiscip Rev Clim Chang 6(1):63-78

Future Earth (2014) Future earth strategic research agenda. International Council for Science (ICSU), Paris 19(105). https://doi.org/10.1016/j.sger.2013.12.003

Giddens A (1976) New rules of sociological method: a positive critique of interpretative sociologies. Hutchinson, London

Hansen JW, Jones JW (2000) Scaling-up crop models for climate variability applications. Agric Syst 65(1):43-72

Heslot N, Akdemir D, Sorrells ME, Jannink JL (2014) Integrating environmental covariates and crop modeling into the genomic selection framework to predict genotype by environment interactions. Theor Appl Genet $127(2): 463-480$

IPCC (2012) Managing the risks of extreme events and disasters to advance climate change adaptation. A special report of working groups I and II of the Intergovernmental panel on climate change. In: Field CB, Barros V, Stocker TF, Qin D, Dokken DJ, Ebi KL, Mastrandrea MD, Mach KJ, Plattner G-K, Allen SK, Tignor M, Midgley PM (eds) Cambridge University Press, Cambridge, p 582

IPCC (2014) Climate change 2014: impacts, adaptation, and vulnerability. Part A: global and sectoral aspects. Contribution of working group II to the fifth assessment report of the Intergovernmental panel on climate change. In: Field CB, Barros VR, Dokken DJ, Mach KJ, Mastrandrea MD, Bilir TE, Chatterjee M, Ebi KL, Estrada YO, Genova RC, Girma B, Kissel ES, Levy AN, MacCracken S, Mastrandrea PR, White LL (eds) Cambridge University Press, Cambridge, p 1132

Jakku E, Thorburn PJ (2010) A conceptual framework for guiding the participatory development of agricultural decision support systems [online]. Agric Syst 103(9):675-682

Jones JW, Hoogenboom G, Porter CH, Boote KJ, Batchelor WD, Hunt LA, Wilkens PW, Singh U, Gijsman AJ, Ritchie JT (2003) The DSSAT cropping system model. Eur J Agron 18:235-265

Jones JW, Antle JM, Basso B, Boote KJ, Conant RT, Foster I, Godfray CJ, Herrero M, Howitt RE, Janssen S, Keating BA, Munoz-Carpena R, Porter CH, Rosenzweig C, Wheeler TR (2017) Toward a new generation of agricultural system data, models, and knowledge products: state of agricultural systems science. Agric Syst 155:269-288 
Keating BA, McCown RL (2001) Advances in farming systems analysis and intervention. Agric Syst 70(2-3): 555-579

Klein RJT, Midgley GF, Preston BL, Alam M, Berkhout FGH, Dow K, Shaw MR (2014) Adaptation opportunities, constraints, and limits. In: Field CB, Barros VR, Dokken DJ, Mach KJ, Mastrandrea MD, Bilir TE, Chatterjee M, Ebi KL, Estrada YO, Genova RC, Girma B, Kissel ES, Levy AN, MacCracken S, Mastrandrea PR, White LL (eds) Climate change 2014: impacts, adaptation, and vulnerability. Part A: global and sectoral aspects. Contribution of working group II to the fifth assessment report of the Intergovernmental panel on climate change. Cambridge University Press, Cambridge, p 899-943

Lambin EF, Meyfroidt P (2010) Land use transitions: socio-ecological feedback versus socio-economic change. Land Use Policy 27(2):108-118

Lane A, Jarvis A (2007) Changes in climate will modify the geography of crop suitability: agricultural biodiversity can help with adaptation [online]. SAT eJournal 4(1):1-12

Lobell DB, Burke MB, Tebaldi C, Mastrandrea MD, Falcon WP, Naylor RL (2008) Prioritizing climate change adaptation needs for food security in 2030 [online]. Science 319(5863):607-610

Lubchenco J (1998) Entering the century of the environment: a new social contract for science. Science 279(5350):491-497

Meinke H, Howden SM, Struik PC, Nelson R, Rodriguez D, Chapman SC (2009) Adaptation science for agriculture and natural resource management - urgency and theoretical basis [online]. Curr Opin Environ Sustain 1(1):69-76

Meza FJ, Silva D, Vigil H (2008) Climate change impacts on irrigated maize in Mediterranean climates: evaluation of double cropping as an emerging adaptation alternative [online]. Agric Syst 98(1):21-30

Milan A, Ruano S (2014) Rainfall variability, food insecurity and migration in Cabricán, Guatemala [online]. Clim Dev 6(1):61-68

Mimura N, Pulwarty RS, Duc DM, Elshinnawy I, Redsteer MH, Huang HQ, Nkem JN, Sanchez-Rodriguez RA (2014) Adaptation planning and implementation. In: Field CB, Barros VR, Dokken DJ, Mach KJ, Mastrandrea MD, Bilir TE, Chatterjee M, Ebi KL, Estrada YO, Genova RC, Girma B, Kissel ES, Levy AN, Mac Cracken S, Mastrandrea PR, White LL (eds) Climate change 2014: impacts, adaptation, and vulnerability. Part a: global and sectoral aspects. Contribution of working group II to the fifth assessment report of the intergovernmental panel on climate change. Cambridge University Press, Cambridge, pp 869898

Naess LO (2013) The role of local knowledge in adaptation to climate change. Wiley Interdiscip Rev Clim Chang 4(2):99-106

National Academy of Sciences, National Academy of Engineering, and Institute of Medicine (2005) Facilitating interdisciplinary research. The National Academies Press, Washington DC. https://doi.org/10.17226/11153

Olsson L, Opondo M, Tschakert P, Agrawal A, Eriksen SH, Ma S, Perch LN, Zakieldeen SA (2014) Livelihoods and poverty. In: Field CB, Barros VR, Dokken DJ, Mach KJ, Mastrandrea MD, Bilir TE, Chatterjee M, Ebi KL, Estrada YO, Genova RC, Girma B, Kissel ES, Levy AN, Mac Cracken S, Mastrandrea PR, White LL (eds) Climate change 2014: impacts, adaptation, and vulnerability. Part a: global and sectoral aspects. Contribution of working group II to the fifth assessment report of the intergovernmental panel on climate change. Cambridge University Press, Cambridge, p 793-832

Orlove B, Roncoli C, Kabugo M, Majugu A (2010) Indigenous climate knowledge in southern Uganda: the multiple components of a dynamic regional system. Clim Chang 100(2):243-265

Patt A, Gwata C (2002) Effective seasonal climate forecast applications: examining constraints for subsistence farmers in Zimbabwe. Glob Environ Chang 12(3):185-195

Pellegrini L, Tasciotti L (2014) Crop diversification, dietary diversity and agricultural income: empirical evidence from eight developing countries [online]. Can J Dev Stud 5189:1-17

Porch TG, Bernsten R, Rosas JC, Jahn M (2007) Climate change and the potential economic benefits of heattolerant bean varieties for farmers in Atlántida, Honduras. J Agric Univ P R 91(3-4):133-148

Quinn CH, Ziervogel G, Taylor A, Takama T, Thomalla F (2011) Coping with multiple stresses in rural South Africa. Ecol Soc 16(3):10

Rahn E, Lederach P, Baca M, Cressy C, Schroth G, Malin D, van Rikxoort H, Shriver J (2014) Climate change adaptation, mitigation and livelihood benefits in coffee production: where are the synergies? Mitig Adapt Strateg Glob Chang 19(8):1119-1137

Rippke U, Ramirez-Villegas J, Jarvis A, Vermeulen SJ, Parker L, Mer F, Diekkrüger B, Challinor AJ, Howden M (2016) Timescales of transformational climate change adaptation in sub-Saharan African agriculture [online]. Nat Clim Chang 6:1-6

Rivington M, Koo J (2010) Report on the meta - analysis of crop modelling for climate change and food security survey. Climate Change, Agriculture and Food Security Challenge Program of the CGIAR, Copenhagen

Rosenzweig C, Elliott J, Deryng D, Ruane AC, Müller C, Arneth A, Boote KJ, Folberth C, Glotter M, Khabarov N, Neumann K, Piontek F, Pugh TAM, Schmid E (2014) Assessing agricultural risks of climate change in 
the 21 st century in a global gridded crop model intercomparison [online]. Proc Natl Acad Sci 111(9):32683273

Rosenzweig C, Jones JW, Hateld JR, Antle JM, Ruane AC, Boote KJ, Thorburn PJ, Valdivia RO, Porter CH, Janssen S, Wiebe K, Mutter CZ, Lifson S, Mencos-Contreras E, Athanasiadis I, Baigorria G, Cammarano D, Descheemaeker K, Hoogenboom G, Lizaso J, McDermid S, Wallach D, Adiku SDK, Ahmad A, Beletse Y, Dileepkumar G, Kihara J, Masikati P, Ponnusamy P, Subash N, Rao KPC, Zubair L, AgMIP Collaborators around the world (2015) “AgMIP Technical Report” USDA 59-3625-1-745

Ruane AC, Cecil LD, Horton RM, Gordon R, McCollum R, Brown D, Killough B, Goldberg R, Greeley AP, Rosenzweig C (2013) Climate change impact uncertainties for maize in Panama: farm information, climate projections, and yield sensitivities. Agric For Meteorol 170:132-145

Schmidt A, Eitzinger A, Sonder K, Sain G (2012) Tortillas on the roaster: full technical report central American Maize-Bean systems and the changing climate. Catholic Relief Service. http://www.crs. org/sites/default/files/tools-research/tortillas-on-the-roaster-full-report 0.pdf. Accessed 14 June 2017

Scoones I, Thompson J, Glean A, Seeram H, Rampersaud R, Cazella AA, Bonnal P, Maluf R, Casas E,Martínez G, and Motta M (2009) Farmer first revisited: Innovation for agricultural research and development. Institute of Development Studies. ITDG Publishing

Shaman J, Solomon S, Colwell RR, Field CB (2013) Fostering advances in interdisciplinary climate science. [online]. Proc Natl Acad Sci U S A 110:3653-3656

Smit B, Pilifosova O (2003) From adaptation to adaptive capacity and vulnerability reduction. In: Smith JB, Klein RJT, Huq S (eds) Climate change, adaptive capacity and development. Imperial College Press, London, p 9-28

Smit B, Wandel J (2006) Adaptation, adaptive capacity and vulnerability. Glob Environ Chang 16(3):282-292

The World Bank (2010) Participatory scenario development approaches for identifying pro-poor adaptation options: Participatory Scenario Development (PSD) approaches for pro-poor adaptation: capacity development Manual. (December)

Vermeulen SJ, Challinor AJ, Thornton PK, Campbell BM, Eriyagama N, Vervoort JM, Kinyangi J, Jarvis A, Laderach P, Ramirez-Villegas J, Nicklin KJ, Hawkins E, Smith DR (2013) Addressing uncertainty in adaptation planning for agriculture [online]. Proc Natl Acad Sci 110(21):8357-8362

Von Bertalanffy L (1968) General systems theory: foundations, development, applications. George Braziller, New York

Whitfield S (2013) Uncertainty, ignorance and ambiguity in crop modelling for African agricultural adaptation [online]. Clim Chang 120(1-2):325-340

Whitfield S (2014) Weighing up the risks: the challenge of studying 'risk' in empirical research [online]. IDS Bull 45(2-3):7-17

Whitfield S, Dixon JL, Mulenga BP, Ngoma H (2015a) Conceptualising farming systems for agricultural development research: cases from eastern and southern Africa. Agric Syst 133:54-62

Whitfield S, Benton TG, Dallimer M, Firbank LG, Poppy GM, Sallu SM, Stringer LC (2015b) Sustainability spaces for complex agri-food systems. Food Security 7(6):1291-1297

World Meterological Organisation (WMO) (2014) Implementation of the global framework for climate services. World Meterological Organisation, Switzerland. http:/www.wmo.int/gfcs/implementation-plan. Accessed 21 March 2017

Young OR, Berkhout F, Gallopin GC, Janssen MA, Ostrom E, Van Der Leeuw S (2006) The globalization of socio-ecological systems: an agenda for scientific research. Glob Environ Chang 16(3):304-316

Ziervogel G, Opere A (eds) (2010) Integrating meteorological and indigenous knowledge-based seasonal climate forecasts for the agricultural sector: lessons from participatory action research in sub-Saharan Africa. International Development Research Centre, Ottawa 